\title{
BLUE SKY RESTRICTIONS ON NEW BUSINESS PROMOTIONS
}

\author{
JAMES S. MOFSKY*
}

Blue sky law restrictions, although often providing a significant impediment to the development of new enterprises, have received little attention in regard to their actual economic effect. The author surveys the various regulatory approaches taken by restrictive and non-restrictive states, exploring the relative economic inhibitions of each. Particular attention is given to the limitations upon financing new businesses, retaining promoter control and insuring a sufficient reward for entrepreneurship.

$\mathbf{P}^{\text {ROMOTers of new ventures are constantly confronted with blue }}$ P sky laws which severely restrict entrepreneurial activities and which often result in innovations either being sold to existing businesses or abandoned entirely, rather than being developed by new firms. Whether the net economic loss emanating from such regulation is insignificant is debatable - but it has never been measured. Federal seeurities regulation and recent dramatic developments in the area of so-called "federal corporation law" have attracted most of the talents and imagination of scholars and practitioners, and consequently the study of the blue sky laws has been neglected. Practically no economic or legal analysis of blue sky law problems exists and seldom are the activities of state administrators reported. In fact, many lawyers are barely cognizant of the existence of the state statutes and the agencies created to administer these laws. The impact of controls in this area, however, is certainly substantial as blue sky regulation beeomes an ever-increasing fact of business life. Surely, the economic effects of such regulation warrant more careful attention than has been received to date.

In theory a promoter satisfies the requirements of the federal securities laws if he fully and fairly discloses the pertinent

\footnotetext{
* Assistant Professor of Law, University of Miami. B.A. 1956, Wesleyan University; LL.B. 1959. Cornell University; LL.M. 1966, University of Miami.

The author is deeply indebted to Dr. Henry G. Manne, the Kenan Professor of Law at the University of Rochester, for his advice in the preparation of this article.
} 
information with respect to his promotion. ${ }^{1}$ The Securities and Exchange Commission is not empowered to make judgments concerning the merits of the venture. However, the full disclosure requirements contained in most blue sky laws are designed to provide state administrators with data from which they can make qualitative decisions regarding the "fairness" of the proposed offering and the "reasonableness" of aspects of the financial plan." If the new enterprise does not meet certain statutory and administrative standards of quality, most state administrators are provided with the means to prevent or stop the sale of the securities in their jurisdictions. ${ }^{3}$ Such regulation frequently comes into immediate conflict with the plans and requirements of the organizers of new firms.

\footnotetext{
' Regarding the full disclosure philosophy underlying the federal securities laws, see $1 \mathrm{~L}$. loss, Securities Regulation 121-28 (2d ed. 1961); H. Sowards, The Federal SECURITIES ACT \& 1.01 (1965).

2 See L. Loss \& E. CowetT, Blue Sky LAw 36-37 (1958).

${ }^{3}$ In those jurisdictions which have adopted $\$$ 306(a) of the Uniform Securities Act, state administrators are empowered to issue stop orders or dcny effectiveness to registration statements for certain stated reasons which include findings that: (1) the offering would work or tend to work a fraud upon purchasers. (2) the underwriting and selling discounts and commissions are unreasonable in amount, (3) the amounts of promoters' profits or participation are unreasonable, or (4) the amounts or kinds of options are unreasonable. For a list of those jurisdictions which have enacted the Uniform Securities Act in whole or in part, see note 12 infra. In eight states, securities administrators are granted authority to deny registration for reasons which include findings: (1) that the issuer is in any way dishonest, (2) that the issuer is of bad business repute, (3) that the issuer's affairs are in an unsound condition, or (4) that the business or the security of the issucr is not based upon sound business principles. See Fla. Stat. AnN. \$ 517.11 (Supp. 1969); lowa Code ANN. $\S 502.10$ (Supp. 1968); La. Rev. Stat. ANN. § 51:709 (1965); N.C. GeN. Stat. \$ 78-11 (1965); Ore. Rev. Stat. § 59.105 (1968); S.D. Code \$ 55,1907 (1939); VT. STat. ANN. $\$ 9$. 4211 (1947); W. VA. CODE ANN. § 3273(10) (1961). Finally, the statutory standards upon which securities may be qualified for sale in some states are phrased in terms of the securities being "fair, just and equitable," and not working a fraud. See Cal. Corp. Code $\$ 25140$ (West Supp. 1968); N.D. CENT. Code § 10-04-08.1 (Supp. 1967); WIS. Stat. ANN. § 189.13 (1957). Based upon the various forms of statutory authority described above, many of the state securities administrators have adopted rules and regulations limiting the amounts of promoters' participation, options and underwriting expenses to specific percentages. See, e.g., those rules cited in notes 29 and 40 infra. State administrators employ many of the foregoing broad standards on a case-by-case basis where a rule in point has not been adopted. Such wide discretion on the part of administrators borders on being absolute in practice; it is unlikely that many issuers would contest an adverse ruling by such administrators. The costs, delays and unfavorable publicity connected with such a challenge would, in most instances, force the issuer to seek alternative means of financing, such as an offering in a less restrictive state. The paucity of cases involving challenge of administrators' broad discretion is some evidence in support of this conclusion.
} 
The problem originates when a person has a new idea but lacks funds to turn it into a tangible reality. He may attempt to sell it outright, if it is patentable, or he may attempt to sell it and reserve a percentage of the profits when the ultimate product or service is marketed. However, it may be difficult or even impossible to find a purchaser who believes in the profitability; it is not uncommon for entrepreneurs to value their creations higher than others are willing to pay. Finally, the organizer may elect to risk promoting it himself and thus capture all of the profits. Thus, forced by circumstances or choice to promote his own firm, he must seek outside venture capital.

Pension funds, banks, insurance companies, and other financial institutions generally rejeet long-term loan applications from new promotions unless there is adequate collateral. ${ }^{4}$ Even assuming the availability of loans for such ventures, it is doubtful whether debt financing is the appropriate method for capitalizing most new firms; the high cost of such loans and the required periodic interest payments in the early stages of the firms' development may be disastrous. ${ }^{5}$ The Small Business Act ${ }^{6}$ has not furnished adequate relief. Although the Small Business Administration may provide the entire capital necessary to promote certain ghetto housing developments, it generally does not make loans to other new businesses unless the loan applicant matches SBA funds on an equal basis.? This financial assistance will not help entrepreneurs with a good idea but no assets. Thus, the equity securities market may be the only source for capitalizing most speculative ventures. And in theory, this market fulfills the requirements of promoters and investors. It permits the promoter to retain control and allows

While these financial institutions may loan funds to firms that survive the "beginning period" and produce evidence of profitability, new promotions are usually formed without the assistance of established financial intermediaries and must depend upon the personal resources of the owners and thcir relatives and friends. See Jones, Financing Small Business, in Creative Business Financing 55-60 (V. Nordin ed. 1968).

'See Federal. Reserve System, 85th Cong., 2d Sess., Report on Financing Small Business 402-03 (Comm. Print 1958); E. Hollander, The Future of Small Business 129 (1967); SBa Management Research Summary, facts About Small Business FInANCING (1967); Wilhelm, How Small Business Competes for Funds, 11 Law \& CONTEMP. PRoB. 220, 225 (1946).

- 15 U.S.C. $\$ 631$ (1964).

' See Small Business Administration, SBA Business Loans (1967). 
distribution of the risk to a number of investors. But the ability of the promoter to utilize this market is severely limited by the federal and state securities laws.

Unless some exemption is available, an offering of securities requires registration under and compliance with the Securities Act of 1933 and the blue sky laws of the states in which the securities are offered for sale. ${ }^{8}$ The most commonly used exemption permits the private or limited offering of securities to a few persons. If such an offering is made on an intrastate basis, promoters need comply only with the provisions of the statutes of the state wherein the securities are offered. ${ }^{9}$ However, if the securities are offered to residents of two or more states, there must be observance of the appropriate private offering provisions of the Securities Act of $1933^{10}$ as well as the state statutes.

There is some form of limited offering exemption available in 47 states." While the Uniform Securities Act has been enacted, in

'The expenses of registration and compliance are considerable, generally running a minimum of $\$ 30,000$ for a full registration under the federal statute plus between $\$ 200$ and $\$ 3,000$ per state, and statutes and rules in most states severely restrict the public promotion of new ventures. It is often difficult if not impossible to secure a reputable underwriter for a venture-capital offering, and most promoters are not capable of effecting a public distribution and then maintaining an "after-market" without the assistance of a qualified underwriter. For these and other reasons, promoters of new enterprises generally attempt to raise capital privately, and accordingly avail themselves of an exemption from registration. For a discussion of the costs of a public offering, see Wheat \& Blackstone, Guideposts for $a$ First Public Offering, 15 Bus. Law. 539 (1960).

- Section 3(a)(11) of the Securities Act of 1933 provides an exemption from registration for "[a]ny security which is part of an issue offered and sold only to persons resident within a single State or Territory, where the issuer of such security is a person resident and doing business within, or, if a corporation, incorporated by and doing business within, such State or Territory." 15 U.S.C. $\S 77(\mathrm{c})$ (1964).

10 The basis of the federal private offering exemption is found in $\S 4(2)$ of the Securities Act of 1933 ("transactions by an issuer not involving any public offering"), 15 U.S.C. § 7(d) (1964). Although there is no "magic" number under the federal act, an early SEC release hinted that twenty-five was the top figure. This number refers to "offerees" and not to ultimate purchasers. These offerees must be financially sophisticated persons who comprise a relatcd and restricted group, and securities may be offered to them only via direct negotiations, without public solieitation or advertisement. Furthermore, each offerec should be furnished adequate information concerning the company's affairs, its financial condition and the use of the proceeds solicited. Purchasers of the securities must take for investment, and in this respect, the usual precautionary practice is to secure investment letters, print restrictive legends. on the face of the certificates and place stop-transfer orders against the shares.

"Although the statutes of Minnesota, Rhode Island, South Dakota and Vermont do not expressly provide for limited offering exemptions, these states have been included in this 
whole, in part or with modification, in 24 states $^{12}$ and the District of Columbia, there still remain wide differences among the state securities laws. It is not surprising, therefore, to find a variety of types of limited offering exemptions. For purposes of simplicity, these exemptions may be generally categorized as follows: (1) exemptions characterized by the number of permissible "offerees,"13 (2) exemptions characterized by the ultimate number

number because the isolated sale exemption is available to the "issuer or owner" in their statutes. MinN. StAT. ANN. $\S 80.06(2)$ (1968); R. 1. GEN. LAws ANN. § 7-11-8(a) (1956); S.D. Code § 55.1904(1) (1939); VT. STAT. ANN. tit. 9, § 4204(3) (1947) ("owner”). Limited offering exemptions are not present in the statutes of New Hampshire, Delaware and Connecticut. However, such exemptions would not be needed in Delaware and Connecticut where there are no statutes requiring registration of securities. Thus, some form of limited offering can be accomplished in all states except New Hampshire. Although the New York statute does not expressly provide for such an exemption, it does exempt offcrings with respect to which a registration statement is not required to be filed under the Securities Act of 1933 for reasons other than the intrastate exemption. See N.Y. GEN. Bus. LAw $\$ 359$ ff(5) (McKinney Supp. 1968). New York has thus, indirectly, adopted the private offering exemption available under the federal act.

${ }^{12}$ Ala., Alas., Ark., Colo., Hawaii, Idaho, Ind., Kan., Ky., Md., Mich., Mo., Mont., Neb., Nev., N.J., N.M., Okla., Ore,; S.C., Utah, Va., Wash., Wyo.

is Exemptions limiting the number of offeres have been enacted in 27 states. ALA. CodE AnN. tit 53, § 38(i) (Supp. 1967); Alaska Stat. ANN. \& 45.55.140(b)(5) (1962); ARK. Stat. ANN. § 67-1248(b)(9) (1966); Colo. Rev. Stat. ANN. § 125-1-13(2)(j) (1963); Fla. Stat. ANN. § 517.06(11) (Supp. 1969); GA. Code ANN. § 97-107(j) (1968); Hawall Rev. LAws § 199-5(i) (Supp. 1965); IDAho Code ANN. § 30-1435(8) (1967); llL. Rev. Stat. ch. $121-1 / 2, \S 137.4(G)$ (Supp. 1969); IND. ANN. STAT. \$ 25-855(b)(10) (Supp. 1968); IowA Code AnN. \$ 502.5(15) (Supp. 1968): Ky. Rev. Stat. \$ 292.410(9) (1962); LA. Rev. Stat. Axi. $\$ 51: 705$ (12) (Supp. 1969); MD. ANN. CodE art. 32A, \$ 26(b)(9) (1967); Mich. STAT. ANN. \$ 451.802(b)(9) (1967); Mo. AnN. Stat. \& 409.402(b)(9) (1967); Mont. Rev. Codes ANN. \$ 15-2014(8) (1967); Neb. Rev. Stat. \& 8-1111(9) (Supp. 1965); Nev. Rev. Stat. $\S 90.075$ (1965); N.J. Stat. ANN. § 49:3-50(b)(9) (Supp. 1967); N.C. Gen. Stat. § 78-4(7) (1965); Okla. Stat. AnN. tit. 71, § 401(b)(9) (1965); Ore. Rev. Stat. § 59.035(12) (1967); S.C. Code AnN. \$ 62-52(9) (1962): TEX. REv. Civ. Stat. ANN. art. 58 1-5(I) (1964); Wash. Rev. Code ANN. § 21.20.320(9) (1961); Wyo. Stat. AnN. § 17-117-14(b)(9) (1965). Most of the foregoing statutes contain exemptions for post-incorporation offers directed to not more than a stated number of persons (ranging from 10 to 25 offerees) during any twelve month period, providing that the seller reasonably believes all the buyers are purchasing for investment and no commission or other remuneration is paid for soliciting offerees. With respect to this post-incorporation exemption, it is not unusual to find promoters exhausting the total number of permissible offerees before a single dollar is raised.

This exemption is supplemented in several states by a pre-incorporation subscription exemption permitting an offering to an unlimited number of persons if no commission or other remuneration is paid, the ultimate number of subscribers does not exceed a stated figure (ranging from 10 to 25 ), and no payment is made by any subscriber. Before payment may be made for pre-incorporation subscriptions, the securities must be registered or an exemption must be found. To avoid registration after obtaining subscriptions, promoters generally rely 
of shareholders of the corporation, ${ }^{14}$ (3) exemptions limited by the number of buyers and a dollar amount, ${ }^{15}$ and (4) isolated sale exemptions available to the issuer. ${ }^{16}$ Statutes of a few states contain more than one of the above exemptions.

While the limited offering exemptions vary in certain respects from state to state, some significant factors remain constant. For example, of the 47 state statutes containing limited offering exemptions, 36 states forbid commissions or other remuneration in the preincorporation and/or post-incorporation stages. ${ }^{17}$ This means that in the great majority of jurisdictions promoters are precluded from using the services of investment bankers or other intermediaries in the private placement of securities.

The prohibition against commissions or other remuneration in connection with a limited offering is intended to prevent the dilution of investors' funds. If promoters and investment bankers were permitted to take large commissions in effecting the private

on the post-incorporation-limited-offering exemption. It should be noted that the pre-incorporation subscription exemption, unlike the post-incorporation exemption, is available even if the subscriptions are offered by advertisement or public solicitation. Several statutes containing post- and pre-incorporation exemptions limit their use to offers by corporations organized in that state. See note 21 infra and accompanying text.

"Statutes in 14 states characterize the exemption in terms of the number of ultimate shareholders after the sale of securities (ranging from 5 to 35 shareholders). The ncw California statute limits the number to five. Commissions or other forms of compensation are prohibited in most of these jurisdictions, and some statutes restrict the cxemption to offers by corporations organized in that state. AR1Z. REv. STAT. ANN. § 44-1844(10) (1967); Cal. Corp. Code $\S 25102$ (h) (West Supp. 1968); lowa Code ANN. $\$ 502.5(15)$ (Supp. 1969); Kan. Stat. ANN. $\$ 17-1262(\mathrm{~h})$ (1963); Me. Rev. Stat. ANN. tit. 32, $\$ 874(9)$ (Supp. 1968); Miss. CODE ANN. \$ 5384.5(9) (Supp. 1968); N.M. STAT. ANN. \$ 48-18-22(J) (1966); Ohio Rev. Code Ann. $\S 1707.03(0)$ (Page 1964); Pa. Stat. Ann. tit. 70, $\S 32(1)(10)$ (1965); TeX. Rev. Civ. Stat. AnN. art. 581-5(I) (1964); UtaH Code ANN. \& 61-1-14(2)(i) (Supp. 1968); VA. Code ANN. § 13.1-514(b)(8) (Supp. 1968); IV. VA. Code ANN. § 3273(4)(h) (1961); WIs. StaT. ANN. § 189.07(1) (1957).

is Tennessee limits the exemption to 30 subscriptions or sales, and a maximum $\$ 100,000$. TENN. CODE ANN. § 48-1632(G) (1964). Statutes in Georgia, Massachusetts and North Dakota limit the exemption in terms of the number of offerees or buyers (15 to 25) and/or a maximum dollar amount $(\$ 25,000)$. The exemption is generally restricted to local corporations, and commissions or other remuneration are prohibited. GA. CODE ANN. $§ 97-$ 107 (i) (1968); Mass. Gen. Laws ANn. ch. 110A, \& 3(I) (Supp. 1966); N.C. Cent. Code \& 10-04-06(9) (Supp. 1967).

"See note Il supra.

"Ala., Alas., Ark., Cal., Colo., Fla., Ga., Hawaii, Idaho, Ill., Ind., Iowa, Kan., Ky., La., Md., Mich., Miss., Mo., Mont., Neb., N.J., N.M., N.C., N.D., Okla., Ore., Pa., S.C., Tenn., Utah, Vt. (VT. Stat. AnN. tit. 9, § 4204(4) (1947)), Wash., W. Va., Wis., Wyo. See notes $13-15$ for citations to statute of the foregoing states. 
placement of securities, the equity of capital-contributing shareholders would be diminished in direct relation to the size of such commissions. However, it may be impossible for the organizers of a new venture to raise the needed funds without the assistance of professional financial intermediaries. It is submitted that some dilution of shareholder equity is a better alternative than the possible abandonment of the proposed business because of the inability to use investment bankers.

As a compromise and to prevent a very great dilution, limits on the amount of permissible commission might be established by statute or administrative rule, and such commissions might be permitted only to registered broker-dealers and not to the promoters of the particular venture. In this connection, most of the states limit the amount of underwriting discounts, commissions and expenses permitted an investment banker in effecting a public offering of securities. However, it is submitted that the better alternative would be to allow commissions to investment bankers without restriction on amounts. Competition in the investment banking industry should result in competitive placement fees, varying with the difficulty of the placement task and the degree of risk. Furthermore, if investors are apprised of the participation of an investment banker in a private placement and the amount of his fee, there is no reason to interfere with the transaction.

There are other reasons justifying the use of investment bankers in this area. Clearly, professional bankers are better equipped than most promoters in placing securities within the limitations of the federal and state exemptions. Fewer violations would tend to occur if such transactions were effected by experts who regularly deal with and have access to the funds of sophisticated investors who could truly fend for themselves. ${ }^{18}$ Such intermediaries would be fully familiar with the limitation on the number of offerees and the identity of investors contemplated by the private offering exemption.

Of course, the cost of a private offering would be increased if bankers were permitted to participate, but this fact does not

\footnotetext{
Ix In SEC v. Ralston Purina Co., 346 U.S. 119 (1953), the Supreme Court held that the applicability of the section 4 exemption should turn on whether the particular class of persons affected needed the protection of the Act or could be expected to fend for itself.
} 
warrant the restriction. Related benefits may well offset the extra cost. Such benefits may include the continued interest of the investment banker in the company with respect to additional financing or a future public offering which might be desirable, not only to the company, but to the banker's customers who are locked in with the company's investment securities. ${ }^{19}$

As a practical matter, promoters who need professional assistance to accomplish a private offering generally go to New York firms who place the securities with residents of New York or one of the other few states which do not proscribe commissions. Thus, New York investment bankers have a virtual monopoly on the private equity-money market. It is submitted that investment firms serve a highly desirable purpose as suppliers of venture capital and that their function in this respect should not be excluded to the profit of New York firms. Moreover, residents of states with such prohibitions should not be denied the opportunity to participate in private placements effected by financial intermediates. It should be noted that while several of the state statutes provide that administrators, by rule or order, may waive or limit the prohibition of commissions or other remuneration, ${ }^{20}$ to the writer's knowledge, there have been no published rules or orders waiving the restrictions.

The restriction limiting the private offering exemption to corporations organized under the laws of the state where the offering is made is common to many of the states. ${ }^{21}$ While research has not revealed stated policies for this limitation, it is suggested that the probable reasons are the taxes and fees which are generated by requiring businesses to incorporate in a state before they can avail themselves of the limited offering exemption. Furthermore, it may be that the requirement of incorporation in a given jurisdiction could result in encouraging firms to establish their businesses in that jurisdiction to avoid the expense of qualifying to do business in jurisdictions other than the state of incorporation.

Under this unwarranted restriction, a New York corporation

\footnotetext{
"To avoid being viewed as a statutory underwriter, purchasers must buy for investment rather than with a view toward distribution; thus their ability to dispose of the acquired stoek is substantially limited. See H. Bloomenthal, Securities Law 146-66 (1966).

- UNIfORM SECURITIES ACT $§ \quad 402$ (b)(9) (1969 version).

21 See notes 13-15 supra.
} 
could not offer or sell its shares to a single person in a state such as Florida. This restriction becomes particularly unreasonable with respect to a New York promoter who forms his firm in his home state but wishes to offer the securities to a few members of his family who reside in California and Florida. Such offerees would not be afforded significantly greater protection as shareholders by virtue of holding shares in a Florida or California corporation rather than a New York corporation, except perhaps with respect to obtaining jurisdiction over a foreign corporation in a suit. Yet there may be sound business reasons for organizing the company in Delaware or in New York where the promoter and active manager resides and where the firm will do its business. Such reasons outweigh the remote possibilities of litigation. Furthermore, the state of incorporation is not a factor with respect to qualifying an issuer's securities in a public offering. In this regard, it is difficult to conceive of a reason for treating close corporations and public companies in different ways.

In all but a few of the states which have a limited offering exemption, state administrators have taken the position, nowhere required by statute, that lawyers, accountants, promoters and incorporators who take shares for their promotional services must be counted in computing the number of offerees or ultimate shareholders available under the exemption. ${ }^{22}$ Thus, if the exemption is limited to 10 offerees and shares are reserved for five or six persons for promotional considerations, the requisite financing can be raised from only four or five outside investors. As the number of capital-contributing offerees becomes smaller, promoters must obviously raise a proportionately greater amount from each offeree; and if the entire capital is contributed by a few persons, it is likely that these persons will demand control of the corporation. The large investor has more to protect than the small one and would, therefore, have a greater interest in securing control. Furthermore, large investors in new businesses generally tend to be more financially sophisticated than do small contributors, and such sophistication is often accompanied by control demands. However, control by outside individuals is

\footnotetext{
22 This information has been obtained through questionnaires sent to state securities administrators by the author.
} 
undesirable to promoters who believe strongly that their innovations, planning and efforts are a greater relative contribution to the new firm than is the investor's capital. Accordingly, it is not surprising to find that promoters desire the investor's money more than his active participation in policy decisions.

The problem of balance of control is a major obstacle in the financing of new businesses through the private offering of equity securities. Many promoters would rather sell their idea or invention outright-if they were able to find a buyer-rather than accept the loss of control over the development of the innovation in a firm where they would participate with only a minority interest. If one sells the idea outright, he is certain of some pecuniary return, but if he participates as a minority stockholder, he cannot be assured that the corporation will pursue the direction which he feels is necessary for profitable development of his innovation.

The number of permissible offerees thus plays a vital role at this stage in the promoters' plans. Because of the problems of balance of control, the restriction of the limited offering exemption to a stated number of offerees is unrealistic, especially in view of the inclusion of insiders in this number. From a policy standpoint, the identity of the offerees is much more important than the number, and should be solely determinative of the availability of the exemption. It is difficult to understand how an offering and sale to 40 or 50 financially sophisticated persons who can fend for themselves would create greater dangers than an offering and sale to ten financially inexperienced widows. Yet the latter placement would be permissible in the Uniform Securities Act jurisdictions whereas the former offering would be prohibited..$^{23}$ Although several statutes provide administrators with authority to increase the number of offerees by rule or order, such rules or orders have not been forthcoming. It is submitted that the private or limited offering, exemption should be revised so that there is no restriction on the number of offerees provided such offerees are financially sophisticated.

The problems regarding the balance of control of the firnı and the limited number of offerees or shareholders may be further

\footnotetext{
2 The offering to ten financially inexperienced widows may not, however, comply with the elements of a private offering under Section 4(2) of the Securities Act of 1933, 15 U.S.C. \& 77(d)(4) (1964).
} 
intensified by a tax consideration. Assuming a promoter of a new venture has secured the requisite financing from the ten permitted offerees and the outsiders are willing to allow the promoter to retain control, the promoter-who received his shares in consideration of ideas, efforts and planning-might be thereupon confronted with a taxable event. ${ }^{24} \mathrm{He}$ may not have sufficient funds to pay the tax unless he is able to borrow against or sells a portion of his shares. But most lenders do not accept investment or control stock as collateral, ${ }^{25}$ and if he were to sell shares. outright to a few persons, control might be shifted away from him. Furthermore, his sale to a few persons shortly after consummation of the corporation's initial financing might destroy the original limited or private offering exemption. ${ }^{26}$ Such additional problems further demonstrate the unrealistic restrictions inherent in the limited offering exemption as presently constituted.

Promoters often seek to avoid these limitations by means of a public offering of securities; and this approach circumvents many of the aforementioned difficulties. A small investor is not likely to demand control, and if the shares can be diffused among a large number of unrelated investors, promoters should be able to retain control with less than a majority of the outstanding shares. Although there are blue sky restrictions on the amount of underwriter's compensation, investment bankers may be used to accomplish the offering. Furthermore, there are no restrictions as to the state where the corporation is organized. Promoters may also plan the capitalization so that they can sell shares to satisfy tax liabilities and still retain control. Finally, the number of offerees may be unlimited.

A public offering therefore seems to solve many of the promoter's problems. However, the promoter cannot simply go from door to door until the requisite capital is raised. Marketing of securities has become a complex, time-consuming and expensive proposition. First of all, the cost of a full registration with the Securities and Exchange Commission may be prohibitive. Even a

\footnotetext{
24 The shares would constitute ordinary income to him.

$\approx$ Professional lenders generally do not accept investment or control stock as collateral, in view of the dictum in SEC v. Guild Films Co., 279 F.2d 485, 489-90 (2d Cir. 1960).

* The various transactions might be integrated and thereby result in too many offeres or ultimate shareholders under the applicable statutes.
} 
"junior" registration under the Regulation A exemption ${ }^{27}$ is expensive and an intrastate offering, exempt from federal registration requirements, must nevertheless be registered with the state securities commissions at considerable cost. ${ }^{28}$

But cost is only the first obstacle. A more significant problem is the restriction on the permissible amount of promotion shares and options. 1deally, the promoter would like to retain 51 percent or more of the equity for himself and publicly sell the remainder. He may feel that such control is necessary for the success of the enterprise and that such a large equity position is proper compensation for his entrepreneurship. But, in almost all of the states, promotion stock, "cheap stock," and options are limited to stated percentages, or amounts which the administrators may deem reasonable. Formal rules with respect to this matter have been adopted in 20 states, ${ }^{29}$ and in 23 states the administrators have discretion to set the amount depending upon the circumstances of each offering. ${ }^{30}$

In the states with formal rules, the promotion stock limitations are characterized in terms of (1) a maximum percentage of the outstanding 'stock after completion of the public offering, ${ }^{31}$ (2) a

\footnotetext{
${ }^{27}$ SEC Reg. A., 17 C.F.R. $\S \S 230.251-263$ (1968).

23 With respect to such expenses, see note 8 supra.

20 CAL. Admis. Code $\$ 260.140 .31$ (1969) (1 Blue Sky L. Rep. 18619 (Dec. 20, 1968)); Nev. Rev. Stat. § 90.155 (1965); Regs. Ariz. Corp. Comm., Order No. S-5, S-7; (I Blue SKY L. RtP. ₹ 6655, 6657 (Oct. 30, 1963)); ARK. (not published); ReGs. Colo. Div. SEC.. Rule V (D) (I Blue Sky L. Rep. I 9706 (Feb. 13. 1967)); Rules Fla. Sec. Comm., 330-1.08 (1 Blue Sky L. Rep. 13,608 (Nov. 7, 1968)); Regs. Idaho Comm'r. Fin. \& 27 (I Blue Sky L. ReP. I 15,616 (Jan. 17, 1968)); Rules \& Regs. under 111. Sec. Law, Rule 150 (1 Blue SKY L. Rep. If 16,627 (Sept. 14, 1967)); Regs. Kan. Sec. Comm'r., art. 81-7-1(C) (2 Blue SKY L. Rep. I 19,707 (Jun. 13, 1966)); Ky. Div. Sec., Supp. Admin. Ruling no. I (2 Blue SKY L. Rep. I 20,601 (Dec. 21, 1966)); Mich. Sec. Bur., Rule 706.6 (2 BLuE SKY L. REP. If 25,635 (Mar. 13, 1969)); Minn. Admin. Rules \& Reg., SDiv 42 (2 Blue Skr L. Rep. I 26,604 (Aug. 12, 1966)); Okla. Sec. Comm. Statement of Policy (2 Blue SKY L. Rep. I' 39,707 (Aug. 'I, 1967)); Ore. (not published); S.D. Regs. Comm'r. Sec., Pt. 11 G (3 BluE SkY L. Rep. If 44,609 (Nov. 15, 1967)); Tenn. Comm'r. of Ins. \& Banking, Admin. Rulings, Pt. I (3 Blue Sky L. Rep. I 45,631 (Nov. 15, 1967)); Tex. Sec. Comm'r. Regs. (3 Blue Sky L. ReP. I 46,601 (Nov. 7, 1968)); Utah Sec. Comm., rorm Letter \#10 (1967); Wash. Adm'r Sec., Rule 11 (3 BLue SKY L. Rep. If 50,611 (Oct. 10, 1968)); Wyo. Secretary of State, Rules \& Reg... ch. IV, \$ I(c) (3 BLUE SKY L. ReP. I 53,612 (April 19, 1968)).

${ }^{30}$ For the statutory authority permitting state securities administrators to set amounts of promoter participation, see, e.g., UNIForm SECURITIES ACT $\S \S 306,412$.

"Not more than $10 \%$ in Colo. and Ky., $15 \%$ in Ariz. and Fla., 33 1/3\% in Ill. and Ore., and $50 \%$ in Idaho and Wash. See note 29 supra.
} 
stated ratio between promotional securities and total securities outstanding after the offering, ${ }^{32}$ (3) the amount of dilution of the public investors' interest, ${ }^{33}$ or (4) a dollar amount which must be paid by promoters in cash or its equivalent depending on the price charged to outside investors. ${ }^{34}$ Several states have adopted two or more of these tests.

In one state, the administrator has published a policy stating: "No promotional or free stock-some consideration may be given to persons for services rendered on a reasonable basis.' 35 Another administrator answered a questionnaire from this writer in the following manner: "[we] generally try to adjust the price to the public to be closer to that issued to promoters. If persuasion does not work, we will permit withdrawal of the application.' '36 A statement of policy adopted by the Midwest Securities Commissioners Association, adhered to by a number of administrators, provides that promotional shares or "cheap stock" shall be "reasonable in amount and the consideration shall have a reasonable relationship to the proposed public offering price.' 37 Thus there may be considerable uncertainty in those jurisdictions which adhere to the vague standard of the Midwest Securities Commissioners policy. The public offering price, however, still provides some limit upon the promotional stock the entrepreneur may retain.

Promoters who cannot afford to purchase shares at the public offering price are thus seriously limited in their participation in the new firm. Although the policy for such restrictions is not explained in the rules, it may be assumed that the objective is to prevent the interests of outside investors from being diluted by virtue of excessive valuation of the entrepreneur's services. This theory

1 to 2 in Cal. and 1 to 3 in Minn. and S.D. See note 29 supra.

s Usually note more than 33 1/3\%. E.g., Ill., Kan., Okla., Mich., Utah. See note 29 supra.

अ For example, the Kentucky rule provides that stock offered to the investing public at $\$ 5.00$ per share may not be purchased by an insider for less than $\$ 2.50$ per share. See note 29 supra.

¿ Utah Sec. Comm., Admin. Policies, Form 1-H (3 Blue Sky L. ReP. If 47,605 (May 17, 1967)).

* This answer was received from the Securities Division, Department of State, State of South Carolina.

7 Statement of Policy on Cheap Stock, June 27, 1968 (1 Blue Sky L. REP. 4761 (Nov. 7. 1968)). 
implies that there is some relationship between the amount of capital contributed by outside investors and the value of the promoter's innovation. ${ }^{38}$ But such an assumption is unwarranted. One innovation may be ultimately worth 1,000 times the initial capital required to promote it, and another innovation may be worth only ten percent of such capital. State securities administrators are certainly no better equipped than the marketplace to evaluate the worth of an idea, yet the statutes give them this power.

With respect to those jurisdictions wherein the administrators have not adopted formal rules for maximum amounts of promotion stock, the promoter might be forced to expend large sums of money and time only to learn that the administrator views the proinoter's proposed participation as unreasonable. A survey of these states reveals that most of the administrators have not even formulated standards or guides by which they determine the permissible number of promotion shares. The unreasonableness of this entire proposition is thus compounded by uncertainty.

The promoter, confronted with these restrictions, might consider several other possibilities for increasing his participation and maintaining control. He might contemplate promoting the corporation with two classes of common stock, retaining the voting stock for himself and selling the non-voting shares to the public; or, he might retain all of the common stock for himself and issue preferred shares to the outside investors. However, such plans will not qualify under the rules of some state securities commissions with respect to many new ventures. ${ }^{39}$ As an alternative, he might consider reserving sufficient options to insure control and provide suitable compensation for his entrepreneurship. But, here again, the promoter is stymied. Most jurisdictions limit the permissible amount of options, often to a number that does not exceed ten percent of the stock outstanding after completion of the proposed

\footnotetext{
${ }^{3 x}$ See Manne \& Mofsky, What Price Blue Sky? Barron's, Aug. 5, 1968, at 5, col. 4.

${ }^{23} \mathrm{See}$, for example, the limitations on the use of preferred stock and non-voting common stock in Rules, Fla. Sec. Comm., 330-1.05, 330-1.09 (I BLUE SKY L. REP. I I 13,605 \& 13.609 (Nov. 7,1968$)$ ). The rationale for the restriction on non-voting common stock is the prevention of voting control of new ventures by persons who do not contribute substantial capital in the organization of the firm. The reason for the limitation on preferred stock is to prevent new ventures from publicly issuing senior securities in the absence of an earnings history to support such securities.
} 
offering. And, in some jurisdictions, underwriters' warrants are included in the ten percent option limitation. ${ }^{40}$

To compensate for the restriction on the permissible amount of promotion stock and options, an entrepreneur might raise the price per share to be paid by the public investors. This at least would increase the net asset value of the promoter's interest. However, many administrators have adopted rules or taken informal positions which, in effect, fix the price for which shares may be sold to outsiders. Such price-fixing is intended to prevent "too much" dilution of the outsiders' interests.

For example, in new ventures, one securities cornmission, without adopting a formal rule, limits the public offering price to two or two and one-half times the consideration paid by insiders. This same commission has adopted a rule which further limits the amount which can be raised publicly; thus, a corporation cannot sell securities in that jurisdiction unless it has a net worth of approximately 25 percent of the amount sought to be raised in the public offering. ${ }^{41}$ To comply with this rule, entrepreneurs often sell shares privately to amass enough net worth to qualify for a public offering. This process can easily result in a loss of control to the promotional group. It is not surprising, therefore, to find many promoters leaving their home states to seek underwriters who can effect public distributions of securities in New York.

Requiring capital investments from entrepreneurs before they may promote new ventures via a public offering is tantamount to a rule restricting entrepreneurial services to the affluent. Such a proposition, if openly suggested, probably would not be condoned, but blue sky administrators do not seem concerned with these matters.

Another problem connected with the restrictions on promotion stock arises because of the rule in most states which requires escrow of promotional shares. Of the 39 states which require escrow arrangements, ${ }^{42} 18$ do not permit release until dividends

- See, e.g., Regs. Colo. Div. Sec., Rule V(G) \& (H) (1 BluE SKY L. Rep. II 9706 (Feb. 13, 1967)).

"Rules, Fla. Sec. Comm., 330-1.04 (I Blue Sky L. Rep. I 13,604 (Nov. 7, 1968)).

- Ala. Code Ann. tit. 53, § 34(b) (Supp. 1967); Alaska Stat. Ann. § 45.55.110(g) (Supp. 1966); ARIz. Rev. Stat. ANN. § 44-1876 (1967); ARK. Stat. ANn. \& 67-1245(g) (1966); Cal. Corp. Code $\S 25141$ (West Supp. 1968); Colo. Rev. Stat. ANn. § 125-I- 
aggregating five to six percent have been earned and/or paid on the outside investor's shares..$^{43}$ The remaining jurisdictions ${ }^{44}$ allow release at the discretion of the state regulators or after a prescribed time period (usually two or three years) ${ }^{45}$

Few new companies earn profits during the first year or two of existence out of which dividends can be paid, and even if profits were earned early in the firm's life, sound business planning might dictate the use of profits in internal expansion and development. It would be unlikely, therefore, that the promoter could realize profits on his stock soon after the promotion of the venture. But if he needs funds to satisfy tax obligations on his shares or if he wishes to make additional use of some profits, he will be forced to seek other means of releasing the stock from escrow. One enticing mcthod might be a merger of the new enterprise with another company which could afford to pay the dividend. As a result, restrictive blue sky laws may foster shotgun mergers.

It is apparent that blue sky legislation may result in important and dangerous economic consequences with respect to three related entrepreneurial problems: financing a new business, promoter

$10(7)$ (1963); FlA. STAT. ANN. $\S 517.18$ (1962); GA. CODE ANN. § 97-104.1(C) (1968); Hawall Rev. Laws § 199-14 (Supp. 1965); IDAHo CODE ANN. § 30-1428 (1967); Ill. Rev. StaT. ch. 121-1/2, \& 137.11(E) (Supp. 1967); IND. ANN. Stat. \& 25-860(j) (Supp. 1968); lowa Code ANN. $\$ 502.20$ (1949); Kan. Stat. ANn. $\$ 17-1259$ (d) (1964); Ky. Rev. Stat. $\S 292.380$ (1963); La. Rev. Stat. ANN. \$ 51:713 (1965); Mich. Stat. ANN. $\S 19.776(305)($ ) (Supp. 1968); Miss. Code ANN. $\& 5364$ (Supp. 1968); Mo. ANN. STat. \& 409.305(f) (Supp. 1968); Mont. Rev. Codes AnN. \& 15-2011 (1967); Neb. Rev. Stat. § 8-1108(2) (Supp. 1965); N.J. Stat. ANN. \& 49:3-61 (Supp. 1967); N.M. Stat. ANN. \& 4818-19(C) (1965); N.C. GeN. Stat. § 78-11(1) (1965); N.D. Cent. Code $\S$ 10-04-08-1(1) (Supp. 1967); Oho Rev. Code ANN. § 1707.09(K) (Page 1964); Okla Stat. AnN. tit. 7I, $\S 305(\mathrm{~g})$ (1965); Ore. Rev. StaT. § 59.085(3) (1967); S.C. Code ANN. § 62-165 (1962); Tenn. Code AnN. \& 48-1650 (1963); Utah Code ANN. \& 61-1-11(7) (Supp. 1968); VT. Stat. ANn. tit. 9, \& 4223 (1947); VA. Code ANN. \& 13.1-5 I0(h) (Supp. 1968); Wash. Rev. Code ANn. \& 21.20.250 (1961); W. VA. Code AnN. \& 3273(16) (1961); Wis. Stat. AnN. $\S 189.17$ (1) (1955); Wyo. Stat. ANN. § 17-117-1l(g) (1965); Minn. Admin. Rules \& Regs., SDiv 43 (2 Blue Sky L. ReP. If 26,604 (Aug. 12, 1966)); S.C. Regs. Comm'r. Sec., Pt. IIG (3 Blue SKY L. ReP. If 44,609 (Nov. 15, 1967)).

Ala., Ark., Colo., Fla., Hawaii, lowa, Kan., Ky., La., Neb., N.M., N.C., N.D., Ohio, Ore., Vt., Va., W. Va. For citations see note 42 supra.

"Alas., Ariz., Cal., Ga., Idaho, Ill., Ind., Mich., Minn., Miss., Mo., Mont., N.J., Okla., S.C., S.D., Tenn., Utah, Wash., Wis., Wyo. For citations see note 42 supra.

4 For additional information concerning the escrow aspects of the state securities laws, see L. Loss \& E. Cowetr, Blue Sky Law 38, 78-79, $311-12$ (1958). See also the statutes cited in note 42 supra. 
control and sufficient reward for entrepreneurship. There are other significant economic ramifications, but these three problems are particularly serious with regard to the development of new firms. If the promoter is forced to give up control by virtue of the restrictions contained in the limited offering exemption or the rules limiting promotion shares, control will shift to those persons who can afford to purchase it. The regulatory system precludes the noasset promoter from competing effectively with investment bankers and affluent persons for control, and accordingly, the latter persons secure control at a lower price than would be paid if the entrepreneur were not hindered by restrictive statutes and rules.

The arguments for a greater freedom of access to the financial market, both private and public, demonstrate some of the fallacies underlying the blue sky laws, especially in connection with the promotion of new ventures. The opposing argument, in favor of the paternalistic approach of securities legislation, is based upon the theory that full and fair disclosure is not enough. This theory submits that there exist fraudulent promoters and unsound business schemes, and that such promoters should not be permitted to take advantage of public investors, even though the whole truth be told in a prospectus cleared with the Securities and Exchange Commission and state agencies.

Advocates of the merit approach to securities regulation contend that the prospectus which has evolved since the enactment of the federal law in 1933 is too long and too complex to be meaningful to the average investor; it may be understood by lawyers and accountants but is beyond the comprehension of most investors. Furthermore, it is contended that the success of certain ventures is just too doubtful or speculative to warrant public participation, in spite of the fact that the doubtfulness and speculative nature of the offering are indicated in large type on the cover page and in the introductory statement of the prospeetus. Thus even when the public offerees are cognizant of the extreme risks involved in certain offerings, their opportunity to speculate is foreclosed. The philosophy underlying the blue sky laws is, in short, the saving of "a fool from his folly."

The merit approach has probably saved some investors from the loss of hard-earned dollars. There is little doubt that there have always been and probably always will be unscrupulous promoters with shaky business schemes, and that the blue sky laws do have an 
impact limiting these abuses. But this reality does not in itself justify the severe form of blue sky regulation. 1ts justification can be based only upon a balancing of interests, whereby the benefits of such regulation measure significantly greater than the costs, and this kind of measurement would most appropriately be of a scientific nature performed by trained economists.

To date, lawyers and economists have not examined the cost to society stemming from blue sky statutes and rules. It is not enough to justify the regulatory scheme with such pat answers as: "the public needs protection." A few fraudulent promoters and unsound business schemes do not in themselves justify such regulation. Surely, the matters deserve a higher level of analysis. While it is not within the scope of this article to devise the kind of analysis needed in this area, one approach might be to compare the economic development of a restrictive state, such as California, with that of New York, a nonrestrictive state. Although other factors contributing to the growth of these states would have to be isolated, such analysis is not beyond the reach of contemporary economists.

It is unlikely that the appropriate study would come from the North American Securities Administrators or from the Midwest Securities Commissioners, because these organizations simply do not have the facilities and personnel necessary for a theoretical and empirical economic analysis. The various state securities commissions, already overburdened with too much work and inadequate staffs, are also not equipped for the task. Perhaps the Securities and Exchange Commission, which enjoys a continuing relationship with the various state administrators, would be the proper organization to conduct the study. Another possibility would be for state law revision commissions to sponsor independent projects by specialists. In any event, it is hoped that this presentation suggests the practical desirability of such studies by a qualified group in the immediate future. 